\title{
Ensaio Uniaxial de Tração dos Tendões dos Músculos Grácil e Semitendinoso Humanos
}

\author{
Uniaxial Traction Test on Human Gracilis and Semitendinous Tendon
}

Sérgio Rocha Piedade ${ }^{1}$, Prof. Dr. Inácio M. Del Fabbro², Prof. Dr. Benedicto de Campos Vidal ${ }^{3}$, Prof. Dr. Reinaldo Gamba4

\section{RESUMO}

O uso de tendões humanos, de forma isolada ou associada, em reconstruções ligamentares do joelho é uma prática usual.

Autilização desses enxertos (tendão patelar, duplo semitendinoso associado ao duplo grácil) apresenta evolução pós-operatória diferente, quando analisados os parâmetros : perda mínima da extensão, deslocamento ântero-posterior (artrômetro KT-2000), retorno as atividades esportivas.

A presente pesquisa tem por objetivo analisar o comportamento mecânico de tendões humanos (grácil e semitendinoso), quando submetidos a ensaios uniaxiais de tração, até a ruptura.

Como parâmetros mecânicos para análise e confronto foram considerados: tensão de ruptura (MPa), deformação relativa, módulo de elasticidade (MPa), energia de ruptura (N.mm) e velocidade de carregamento $(\mathrm{mm} / \mathrm{s})$.

Os resultados permitiram concluir que:

- o tendão do músculo semitendinoso é mais resistente que o tendão do músculo grácil; apresenta menores deformações relativas; acumula maior energia de ruptura;

- a utilização destes tendões como enxerto único, impõe uma análise mecânica mais detalhada, pois apresentam comportamento mecânico distinto e são materiais história e tempo - dependentes (viscoelásticos).

\section{SUMMARY}

The use of isolated human tendons as well as in associated forms on knee reconstrution has become na usual practice.

The literature reveals that the use of implants of patellar tendon as well as the double semitendinous tendon associated to the double gracilis tendon exhibits different post surgical evolution related to the minimal extension loss, anterior-posterior displacement (KT-1000 artrometer), as well as to the sport activities.

This research work aim to analyze the mechanical behavior of human tendons (gracilis and semitendinous) subject to uniaxial traction to failure.

The mechanical parameters considered includes: stress at failure $(\mathrm{MPa})$, strain energy at failure $(\mathrm{N} . \mathrm{mm})$ and strain rate $(\mathrm{mm} / \mathrm{mm})$.

Results induced to the following conclusions:

- tendon of semitendinous muscle is more resistent than the tendon gracilis muscle; exhibits lower strain, stores higher level of strain energy at failure.

- as they present distinct mechanical behavior, it would be necessary to acomplish a more detaield analysis to face the time and history dependence wich are the basic characteristics of viscoelastic materials.
Trabalho realizado no Departamento de Ortopedia e Traumatologia da Faculdade de Ciências Médicas da Universidade Estadual de Campinas. Extrato da Dissertação de Mestrado de Sérgio Rocha Piedade, realizada no Laboratório da FEAGRI-Unicamp, em 1998.

1. Mestre em Cirurgia-FCM-Unicamp - Médico contratado do Departamento de Ortopedia e Traumatologia do HC-Unicamp.

2. Prof. Dr. do Departamento de Máquinas Agrícolas da FEAGRI - Unicamp.

3. Prof. Titular do Departamento de Biologia Celular do Instituto de Biologia da Unicamp.

4. Prof. Dr. do Departamento de Ortopedia e Traumatologia do HCUnicamp.
This investigation was carried out in the Orthopedics and Traumatology Department, College of Medical Sciences (FCM), State University of Campinas (Unicamp). Excerpt of the Sérgio Rocha Piedade's Master Degree Dissertation at the FEAGRI-Unicamp Laboratory, 1998.

1. Master in Surgery - FCM-Unicamp. Orthopedics and Traumatology Department. Physician, HC-Unicamp.

2. Professor Doctor, Orthopedics and Traumatology Department, HCUnicamp

3. Head Professor, Cellular Biology Department, Biology Institute, Unicamp.

4. Professor Doctor, Orthopedics and Traumatology Department, HCUnicamp. 


\section{INTRODUÇÃO}

A movimentação das estruturas esqueléticas é estabilizada e guiada pelos ligamentos, ou seja, bandas de tecido conectivo frouxo que atravessam a articulação e unem o esqueleto: WOO, SMITH, JOHNSON, (1994). Tendões e ligamentos são estruturas colágenas.

O colágeno é definido como uma família de proteínas altamente conservadas, do ponto de vista evolutivo. É encontrado desde as esponjas até o homem. Neste, perfaz 33\% do seu peso corpóreo. Sem colágeno não haveria ossos, dentina, pele, tendões e inúmeras outras estruturas, como os vasos (veias, artérias e capilares) e as tramas fibrosas de órgãos internos. (VIDAL, 1990)

Assim sendo, o comportamento dos materiais biológicos, diante dos esforços solicitantes, foi estudado por MASE (1970), por meio de seus planos elásticos de simetria.

WOO et al. (1994) comentam que, quando se analisa mecanicamente corpos de prova do mesmo material, mas com área de secção distinta, observa-se que aqueles que têm maior secção suportam maior força de ruptura. No entanto, considerandose a tensão de ruptura determinada pela divisão da força de ruptura pela secção média, os valores tendem a ser iguais.

CABAUD (1983) comenta que os principais fatores que determinam a resistência dos ligamentos são o tipo e a forma destes e a velocidade de carregamento.

SMITH, LIVESAY, WOO (1993) consideram a velocidade de ensaios mecânicos segundo 3 categorias: lenta $(0,003 \mathrm{~mm} / \mathrm{s})$, média $(0,3 \mathrm{~mm} / \mathrm{s})$ e rápida $(113 \mathrm{~mm} / \mathrm{s})$.

Segundo WOO et al. (1994), a carga de ruptura é o parâmetro mais afetado pela 'razão de tensão', atingindo valores 30\% maiores nas razões mais elevadas.

AGLIETTI et al. (1994) realizaram um estudo prospectivo com 60 casos de reconstrução do ligamento cruzado anterior do joelho. Foram utilizadas aleatória e alternadamente duas opções de enxerto : o tendão patelar e o duplo semitendinoso associado ao duplo grácil. Os autores concluíram que o duplo semitendinoso associado ao duplo grácil deve ser reservado somente para casos selecionados, enquanto o tendão patelar é a opção de rotina.

Este trabalho teve por objetivo analisar o comportamento mecânico de tendões humanos (grácil e semitendinoso), quando submetidos a ensaios uniaxias de tração, até o ponto de ruptura.

Analisaram-se os parâmetros mecânicos: tensão de ruptura $(\mathrm{MPa})$, deformação relativa, módulo de elasticidade (MPa) e energia de ruptura (N.mm), todos em função da velocidade de carregamento.

\section{INTRODUCTION}

The movement of skeletal structures is stabilized and guided by ligaments, that is, bands of loose connective tissue which cross the joint and tie the skeleton: WOO, SMITH, JOHNSON, (1994). Tendons and ligaments are collagenous structures.

Under the evolutive point of view, collagen is defined as highly conserved proteins. It is found from the sponges to the human beings. In man, represents $33 \%$ of body weight. Without collagen, there would not be bones, dentin, skin, tendons and a number of other structures as vessels (veins, arteries and capillaries) and the fibrous texture of the organs. (VIDAL, 1990).

Thus, the behavior of the biological materials when submitted to solicitant strains was studied by MASE (1970) using elastic simmetry plans.

WOO et al. (1994) state that when samples of the same material are mechanically analyzed, though with distinct surface areas, those with greater section resist more the rupture force. However, considering the rupture strain determined by division of the rupture force by the mean section, the numbers tend to be the same.

CABAUD (1983) states that the main factors which determine resistance of the ligaments are type, form and loading speed.

SMITH, LIVESAY, WOO (1993) define speed in mechanical tests in three categories: slow $(0.003 \mathrm{~mm} / \mathrm{s})$, average $(0.3 \mathrm{~mm} / \mathrm{s})$, and quick $(113 \mathrm{~mm} / \mathrm{s})$.

According to WOO et al. (1994), the parameter rupture load is the most affected by the "strain ratio" reaching values 30\% greater in the higher proportions.

AGLIETTI et al. (1994) carried out a prospective study with 60 cases of anterior cruciate ligament reconstruction of the knee. Two options of grafts were randomly and alternatively used: the patellar tendon and the doubled semitendinous associated to the doubled gracilis. The authors concluded that the doubled semitendinous associated to the doubled gracilis must be the choice only in selected cases, while the patellar tendon is a routine option.

The aim of this study was to analyze the mechanical behavior of human tendons (gracilis and semitendinous) when submitted to uniaxial traction until rupture.

Mechanical parameters were analyzed: rupture strain (Mpa), relative deformation, elasticity module (Mpa) and rupture energy (N.mm), all of them as a function of the loading speed. 


\section{MATERIAL E MÉTODOS Material}

Utilizaram-se tendões dos músculos grácil e semitendinoso de cadáveres com tempo de óbito superior a 12 horas e inferior a 36 horas.

O tempo de óbito foi determinado com base nas informações colhidas e no estado de rigidez cadavérica, conforme descrito por ARBENZ (1988) e ZACHARIAS \& ZACHARIAS (1991).

O uso dos tendões humanos recebeu aprovação da Comissão de Ética Médica do Hospital de Clínicas da Unicamp, do Departamento de Medicina Legal da Unicamp e do Serviço de Medicina Legal do município de Campinas.

Os tendões foram obtidos de cadáveres com idade média de 22 anos (mínimo de 16 anos e máximo de 27 anos). As causas das mortes foram: lesão por arma de fogo (4) e politrauma (5). Foram estudados 36 tendões, sendo 18 do músculo grácil e 18 do músculo semitendinoso.

\section{MATERIAL AND METHODS Material}

Tendons of the gracilis and semitendinous muscles from corpses at least 12 hours and at most 36 hours after death.

The period after death was determined considering information provided and rigor mortis, according to ARBENZ (1988) and ZACHARIAS \& ZACHARIAS (1991).

The use of human tendons was approved by the Medical Ethics Committee of the "Hospital das Clínicas" (HC) Legal Medicine Department, Unicamp, and by the Campinas Municipality Legal Medicine Service.

The tendons were taken from corpses of subjects mean aged 22 years (minimum 16 years and maximum 27 years). The causes of death were: lesion by firegun (4), and polytrauma (5). Thirty-six tendons were studied, 18 from the gracilis muscle and 18 from the semitendinous muscle.

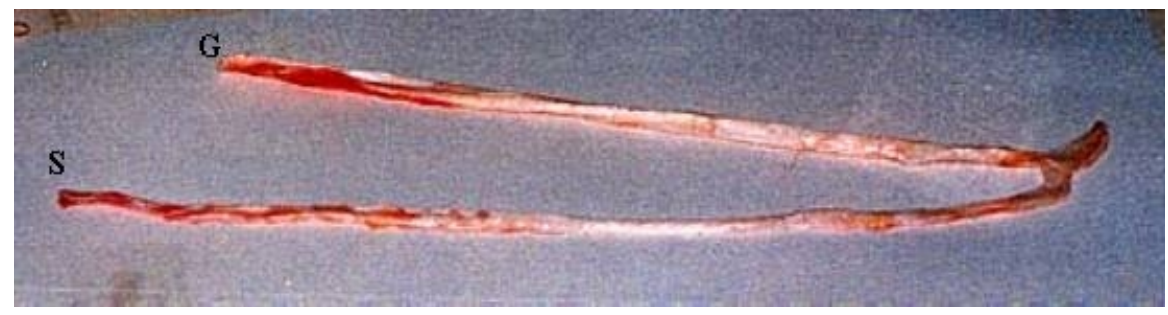

FOTO 1 - Detalhe dos tendões dos músculos grácil e semitendinoso.

\section{Conservação}

A necessidade de se manterem as propriedades físicas e mecânicas dos corpos de prova, associada à dificuldade prática de se realizarem os ensaios, no momento da obtenção dos corpos de prova, determinou a estocagem dos tendões humanos e bovinos.

Os tendões humanos foram acondicionados em sacos plásticos, após identificação. A ficha de identificação constou do número do corpo de prova, sexo, lado, idade, causa mortis.

Os tendões foram mantidos em temperatura de $--20^{\circ} \mathrm{C}$. $\mathrm{O}$ descongelamento foi feito em temperatura ambiente $\left(27^{\circ} \mathrm{C}\right)$, com o material submerso em solução salina (S.F. 0,9\%).

\section{MÉTODO}

\section{Determinação de medidas lineares}

A não uniformidade das dimensões dos corpos de prova implicou na adoção do conceito de 'secção média', vale a pena salientar que esta é característica de todos os tendões biológicos (humanos e animais).

Analisaram-se dois métodos para a determinação da seção média: o paquimétrico e o volumétrico.

\section{Conservation}

The need to maintain the physical and mechanical characteristics of the samples associated to the practical difficulties of sampling demanded storage of human and cattle tendons.

The human tendons were preserved in plastic bags, after identification. The identification card contained the number of the sample, sex, laterality, age, causa mortis.

The tendons were maintained at $-20^{\circ} \mathrm{C}$. Defrost was carried out at room temperature $\left(27^{\circ} \mathrm{C}\right)$ emerging the material in saline (S.F. $0.9 \%)$.

\section{METHOD}

\section{Determination of linear measures}

The non-uniformity of the samples dimension implied the adoption of the "mean section" concept; it is worthwhile to emphasize that this is a characteristic of all biological tendons (human and animal).

Two methods were used to determine the average section: pachymetric and volumetric. 


\section{Obtenção das garras para ancoragem dos corpos de prova}

Após a realização de um conjunto de testes preliminares, adotou-se um garra composta de 2 chapas metálicas com forma sinusoidal no seu interior, associada a ranhuras longitudinais no seu longo eixo.

A fixação dos tendões às garras fez-se com a utilização de 4 parafusos, dispostos um em cada canto da placa.

Vale salientar que se determinou uma tensão uniforme para todos os parafusos por intermédio da medição do torque.

\section{Máquina de ensaio}

Os ensaios foram realizados com o auxílio de uma prensa modelo Otawa Texture Co., células de carga da Berg Cell, um amplificador extensiométrico Kyowa, computador Notebook 486 DX4-100, marca Digimac, cartão de aquisição PCMCIA. O software utilizado foi o DAQWARE.

Os testes uniaxiais de tração foram realizados com 5 velocidades diferentes $(\mathrm{V} 1=0,76 \mathrm{~mm} / \mathrm{s} ; \mathrm{V} 2=1,45 \mathrm{~mm} / \mathrm{s} ; \mathrm{V} 3=2,16 \mathrm{~mm} / \mathrm{s}$; $\mathrm{V} 4=2,78 \mathrm{~mm} / \mathrm{s}$ e $\mathrm{V} 5=3,23 \mathrm{~mm} / \mathrm{s}$ ).

\section{RESULTADOS}

TABELA 1- Valores médios de tensão de ruptura, deformação relativa, módulo de elasticidade, energia de ruptura para o tendão do músculo grácil em função das velocidades de carregamento adotadas.

\section{Clamps to anchor the samples}

After the preliminary set of tests, clamps composed by 2 metalic plates with inner sinusoidal form associated to longitudinal grooves in its long axle were adopted.

Fixation of the tendons to the clamps was carried out using screws in the 4 corners of the plate.

Uniform strain was determined for all the screws using torque measurement.

\section{The test machine}

The test equipment was made up by: Otawa Texture Co. press, Berg Cell loading cells, Kyowa extensiometric amplifier, DX4-100 Digimac 486 Notebook Computer, PCMCIA acquisition card. The software was DAQWARE.

The uniaxial traction tests were carried out with 5 different speeds N1 $=0.76 \mathrm{~mm} / \mathrm{s} ;$ V2 $=1.45 \mathrm{~mm} / \mathrm{s} ;$ V3 $=2.16 \mathrm{~mm} / \mathrm{s} ;$ V $42.78 \mathrm{~mm} / \mathrm{s}$ and $\mathrm{V} 5=3.23 \mathrm{~mm} / \mathrm{s}$ )

\begin{tabular}{ccccc}
\hline $\begin{array}{c}\text { Velocidade de } \\
\text { carregamento }\end{array}$ & $\begin{array}{c}\text { Tensão de ruptura } \\
\text { Rupture strain }\end{array}$ & $\begin{array}{c}\text { Módulo de elasticidade } \\
\text { Deformação relativa } \\
\text { Relative deformation }\end{array}$ & $\begin{array}{c}\text { Energia de ruptura } \\
\text { Pupture energy }\end{array}$ \\
Loading speed $(\mathrm{mm} / \mathrm{s})$ & $(\mathrm{MPa})$ & 0,31 & 67,92 & $(\mathrm{~N} \cdot \mathrm{mm})$ \\
\hline 0,76 & 21,57 & 0,46 & 45,79 & 729,98 \\
\hline 1,45 & 18,00 & 0,53 & 28,01 & 647,54 \\
\hline 2,16 & 15,14 & 0,45 & 38,42 & 612,05 \\
\hline 2,78 & 16,66 & 0,41 & 50,96 & 633,89 \\
\hline 3,23 & 18,25 & 0,43 & 46,22 & 631,03 \\
\hline Média & 17,92 & & & \\
\hline
\end{tabular}

TABELA 2 - Valores médios de tensão de ruptura, deformação relativa, módulo de elasticidade, energia de ruptura para o tendão do músculo semitendinoso em das velocidades de carregamento adotadas.
TABLE 2- Mean values of rupture strain, relative deformation, elasticity module, rupture energy for the semitendinous muscle tendon as a function of the loading speeds.

\begin{tabular}{ccccc}
\hline $\begin{array}{c}\text { Velocidade de } \\
\text { carregamento }(\mathrm{mm} / \mathrm{s})\end{array}$ & $\begin{array}{c}\text { Tensão de ruptura } \\
(\mathrm{MPa})\end{array}$ & Deformação relativa & $\begin{array}{c}\text { Módulo de elasticidade } \\
(\mathrm{MPa})\end{array}$ & $\begin{array}{c}\text { Energia de ruptura } \\
(\mathrm{N} . \mathrm{mm})\end{array}$ \\
\hline 0,76 & 15,99 & 0,47 & 45,27 & 1133,40 \\
\hline 1,45 & 21,87 & 0,21 & 113,89 & 1162,40 \\
\hline 2,16 & 17,59 & 0,16 & 107,20 & 665,10 \\
\hline 2,78 & 22,22 & 0,27 & 82,25 & 1052,40 \\
\hline 3,23 & 21,83 & 0,40 & 65,38 & 1334,30 \\
\hline Média & 19,90 & 0,30 & 82,80 & 1069,52 \\
\hline
\end{tabular}




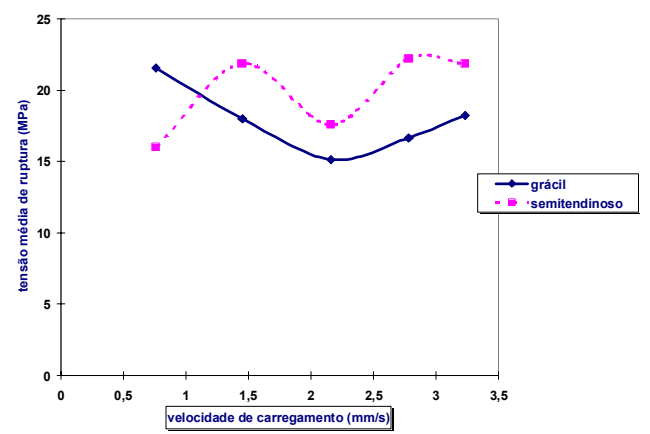

Figura 1 - Confronto dos valores médios das tensões de ruptura dos tendões dos músculos grácil e semitendinoso em função da velocidade de carregamento.

Figure 1 - Comparison between the mean values of the rupture strain for the gracilis and semitendinous muscles tendons as a function of the loading speed.

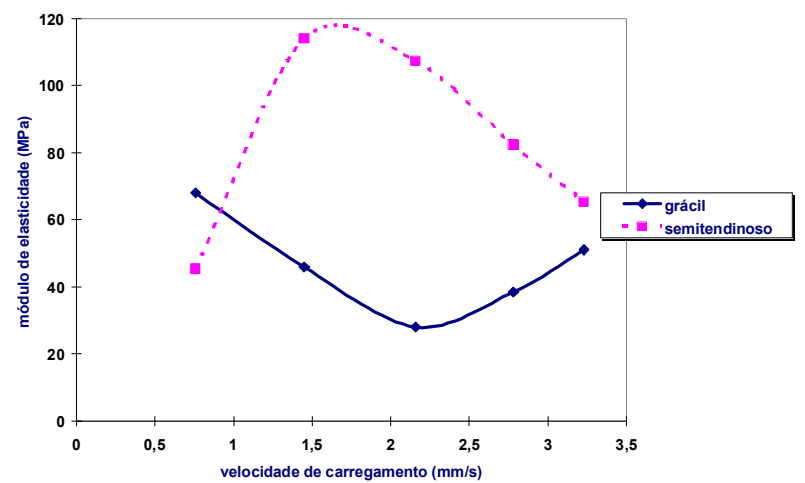

Figura 3 - Confronto dos valores médios do módulo de elasticidade dos tendões dos músculos grácil e semitendinoso em função da velocidade de carregamento.

Figure 3 - Comparison between the mean values of the elasticity module for the gracilis and semitendinous muscles tendons as a function of the loading speed.

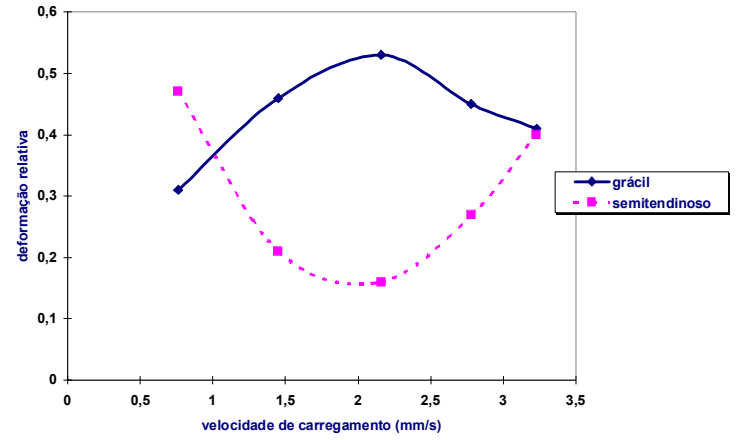

Figura 2 - Confronto dos valores médios de deformação relativa dos tendões dos músculos grácil e semitendinoso em função da velocidade de carregamento.

Figure 2 - Comparison between the mean values of the relative deformation for the gracilis and semitendinous muscles tendons as a function of the loading speed.

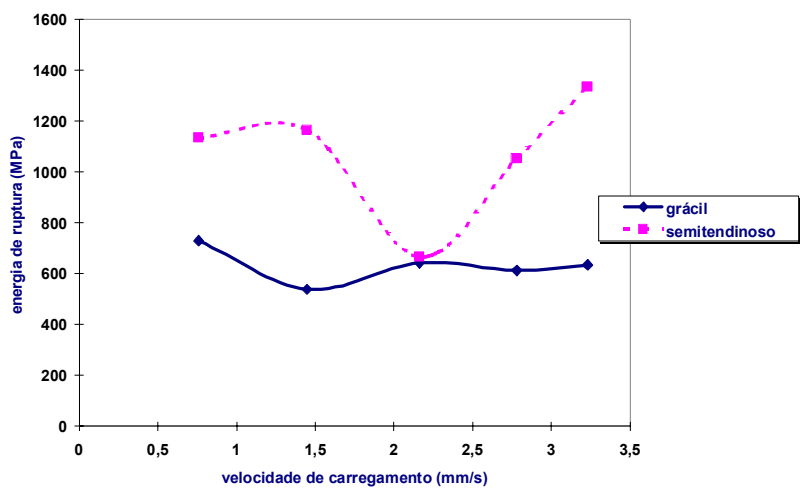

Figura 4 - Confronto dos valores médios de energia de ruptura dos tendões dos músculos grácil e semitendinoso em função da velocidade de carregamento.

Figure 4 - Comparison between the mean values of the rupture energy for the gracilis and semitendinous muscles tendons as a function of the loading speed. 


\section{DISCUSSÃO}

Com os dados das Tabelas 1 e 2 elaboram-se as Figuras de 1 a 4, onde os parâmetros : tensão de ruptura, deformação relativa, energia de ruptura e módulo de elasticidade foram confrontados com as diferentes velocidades de carregamento.

Nas Figuras de 1 a 4, onde as duas tensões expressam o módulo de elasticidade e a tensão de ruptura, observa-se que, para velocidades acima de $1 \mathrm{~mm} / \mathrm{s}$, o tendão do músculo semitendinoso suporta maiores tensões.

$\mathrm{Na}$ Figura 2, nota-se que para velocidades de carregamento acima de $1 \mathrm{~mm} / \mathrm{s}$, o tendão do músculo grácil apresenta maiores deformações relativas.

$\mathrm{Na}$ Figura 4, a energia de ruptura acumulada do tendão do músculo semitendinoso é maior $(69,48 \%)$ que a correspondente do tendão do músculo grácil.

O exame das figuras mostra que, para as condições do ensaio e feitas as ressalvas já assinaladas, o tendão do músculo semitendinoso é mais resistente; apresenta menores deformações relativas e acumula maior energia de ruptura

Observamos que o tendão do músculo semitendinoso foi 30,23 \% menos deformável que o tendão do músculo grácil, fato que pode justificar as conclusões

apresentadas por AGLIETTI et al. (1994) quando da utilização destes tendões, em reconstruções ligamentares.

$\mathrm{Na}$ análise das tensões médias de ruptura, os tendões apresentaram valores situados numa faixa de 15 a $22 \mathrm{~N} / \mathrm{mm}$. O tendão do músculo semitendinoso obteve valores médios de tensão de ruptura 4,21 \% maiores aos obtidos pelo tendão do músculo grácil.

Estes tendões são empregados como opções na reconstrução do ligamento cruzado anterior do joelho. Sua utilização pode ser feita de maneira isolada ou em associação destes dois tendões dobrados, de forma a prover uma maior área de secção transversal do enxerto, aumentando assim, a sua capacidade de suportar tensão.

As diferenças no comportamento mecânico devem ser levadas em consideração quando, ao realizarmos uma reconstrução ligamentar do joelho, a nossa opção de enxerto for um duplo semitendinoso associado ao grácil duplo.

No entanto, em se tratando de materiais história, tempodependentes, ensaios específicos deverão ser realizados, para melhor avaliação das interações ocorridas no ato cirúrgico e nas fases subseqüentes de integração do enxerto.

\section{DISCUSSION}

Using data from Tables 1 and 2, Figures 1 to 4 were constructed comparing the parameters rupture strain, relative deformation, rupture energy and elasticity module with different loading speeds.

In Figures 1 to 4 where the two strains express the elasticity module and the rupture strain, for speeds above $1 \mathrm{~mm} / \mathrm{s}$, the semitendinous muscle endures greater strain.

In Figure 2, for loading speeds above $1 \mathrm{~mm} / \mathrm{s}$ the gracilis muscle tendon presents greater relative deformations.

In Figure 4, the accumulated rupture energy for the semitendinous muscle tendon is higher (69.48\%) than for the gracilis muscle tendon.

The analysis of the figures shows that, under the test conditions, the semitendinous muscle tendon is more resistant; it shows smaller relative deformations and accumulates more rupture energy.

We observed that the semitendinous muscle tendon was $30.23 \%$ less deformable than the gracilis muscle tendon, and this can justify the conclusions reached by AGLIETTI et al. (1994) when these tendons were used in ligament reconstruction.

For mean rupture strain, the values ranged from 15 to 22 $\mathrm{N} / \mathrm{mm}$. The semitendinous muscle tendon produced mean values for rupture strain $4.21 \%$ higher than the gracilis muscle tendon.

These tendons are used as options in the reconstruction of the anterior cruciate ligament of the knee. Their utilization can be in isolation or combining two doubled tendons, as to provide a greater cross section of the graft, increasing its ability to endure strain.

When carrying out a ligament reconstruction in the knee, the different mechanical behaviors must be considered when the graft option is a doubled semitendinous tendon associated to a doubled gracilis.

Notwithstanding, considering the history and time dependence of the materials, specific tests must be carried out to better evaluate the interactions which occur during surgery and in the subsequent phases of graft integration. 


\section{CONCLUSÃO}

Os resultados permitiram concluir que:

- o tendão do músculo semitendinoso é mais resistente que o tendão do músculo grácil; apresenta menores deformações relativas; acumula maior energia de ruptura;

- a utilização destes tendões como enxerto único, impõe uma análise mecânica mais detalhada, pois apresentam comportamento mecânico distinto e são materiais história e tempo - dependentes (viscoelásticos).

\section{CONCLUSION}

The results have shown:

- the semitendinous muscle tendon is more resistant than the gracilis muscle tendon; it presents smaller relative deformations and accumulates more rupture energy

- the utilization of these tendons as a single graft demands a more detailed mechanical analysis, since they have a distinct mechanical behavior and are history- and time-dependent materials (viscoelastic).

\section{REFERÊNCIAS}

- AGlietti, P.; BUZZI, R.; ZACCHEROTTI, G.; DE BIASE, P.: Patellar tendon versus doubled semitendinosus and gracilis tendons for anterior cruciate ligament reconstruction. Am.J.SportsMed., 22:211 - 218, 1994.

- ARBENZ, G.O. Tanatologia Forense.: In: Medicina legal e antropologia forense, Rio de Janeiro, Atheneu, 1988. P.398-399.

- CABAUD, H. E.: Biomechanics of the anterior criciate ligament. Clin. Orthop., (172):27-31, 1983

- GARDNER, E.; GRAY, D.J.; O'RAHILLY, R.: Coxa e Joelho, Rio de Janeiro, Guanabara, 1978. In: Anatomia p.206 - 221.

- MASE, G.E. Linear elasticity. In: Continuum mechanics. New York, Mcgraw-Hill, 1970. p.140 - 159

- SMITH, B.A ; LIVESAY, G. A; WOO, S.L.Y.: Biology and biomechanics of the anterior cruciate ligament. Clin. Sports Med., 12:637-670, 1993.

- VIDAL, B. de C. Colágeno, uma proteína especial, medicina e biologia. In: Brazilians Congress on Proteins, 1, cidade, 1990. Proceedings. Cidade, 1990. p.449-473.

- WOO, S.L.Y; SMITH, B. A.; JOHNSON, G. A. Biomechanics of knee ligaments., Baltimore, Willians \& Wilkins, 1994 In: FU, F.,H.; HARNER,C. D.; VINCE,K.G, Knee Surgery. p.155 - 172.

- ZACHARIAS, M.; ZACHARIAS, E.: Dicionário de medicina legal 2.ed. rev.amp. São Paulo, Ed. Universitária,1991. p.411. 